\title{
A geographical study of the risk factors of a differentiated transmission of malaria in two districts of Bouaké (Ivory Coast)
}

Étude géographique des facteurs de risque d'une transmission différenciée du paludisme dans les quartiers Kennedy et Dar-Es-Salam 1 dans la ville de Bouaké (Côte d'Ivoire)

Kouassi Arsène Adou, Akre Maurice Adja, Dounin Danielle Zoh, Dimi Théodore Doudou, Péga Tuo, Kouassi Paul Anoh and Florence Fournet

\section{OpenEdition} Journals

Electronic version

URL: https://journals.openedition.org/rfst/770

DOI: $10.4000 /$ rfst. 770

ISSN: 2492-3672

Publisher

Espaces et SOciétés (UMR 6590)

Electronic reference

Kouassi Arsène Adou, Akre Maurice Adja, Dounin Danielle Zoh, Dimi Théodore Doudou, Péga Tuo, Kouassi Paul Anoh and Florence Fournet, "A geographical study of the risk factors of a differentiated transmission of malaria in two districts of Bouaké (Ivory Coast)", Revue francophone sur la santé et les territoires [Online], Varia, Online since 27 September 2019, connection on 03 November 2021. URL: http://journals.openedition.org/rfst/770 ; DOI: https://doi.org/10.4000/rfst.770

This text was automatically generated on 3 November 2021

\section{(c) (i) (2)(2)}

La Revue francophone sur la santé et les territoires est mise à disposition selon les termes de la Licence Creative Commons Attribution - Pas d'Utilisation Commerciale - Partage dans les Mêmes Conditions 4.0 International. 


\title{
A geographical study of the risk factors of a differentiated transmission of malaria in two districts of Bouaké (Ivory Coast)
}

\author{
Étude géographique des facteurs de risque d'une transmission différenciée du \\ paludisme dans les quartiers Kennedy et Dar-Es-Salam 1 dans la ville de Bouaké \\ (Côte d'Ivoire)
}

Kouassi Arsène Adou, Akre Maurice Adja, Dounin Danielle Zoh, Dimi Théodore Doudou, Péga Tuo, Kouassi Paul Anoh and Florence Fournet

1 Malaria is a parasitic vector disease whose transmission is linked to a combination of multiple factors related to the vector, the parasite, the human host and its environment. In addition to the high prevalence in the tropical zone, the endemic malaria area, there are significant disparities in the transmission of the disease between rural and urban areas, where the highest prevalence of malaria is observed, but also within the cities themselves. While the city, which appears to be unfavourable to the vector and should therefore contribute to reducing malaria transmission, can be observed to maintain it. However, the transmission is uneven because of certain intrinsic characteristics of the city described as heterogeneous, dense and open.

2 In Bouaké, the second largest city in the Ivory Coast after Abidjan, several years of military-political crisis have resulted in emptying some neighborhoods where the bush has regained ground, increasing the density where populations have remained, disrupting the health care system and weakening the economic power of the city dwellers.

Using a geographical approach, our study aimed to measure the risk of malaria transmission in urban sub-spaces illustrating the changes undergone by the city during the crisis and to identify the factors that make it possible to explain the spatial disparities in the distribution of malaria. 
4 A geographical survey identified Kennedy and Dar-Es-Salam 1 as urban sub-spaces. An update of land use was conducted using field surveys and Google Earth to establish a geographical database for use in the analysis of sociological, parasitological and entomological data which were collected during several field surveys.

5 The land use update showed that only $50.5 \%$ of the developed lots were inhabited in Kennedy, compared with 91.5\% in Dar-Es-Salam 1. Parasitological data showed that the prevalence of malaria was significantly higher at Kennedy (33.5\%) compared to Dar-EsSalam $1(10.2 \%)(p=0.0001)$. Similarly, the aggressiveness of vector mosquitoes (Anopheles gambiae s.l.) was higher in Kennedy $(20.6$ p / h / n) than in Dar-Es-Salam 1 $(1.2 \mathrm{p} / \mathrm{h} / \mathrm{n})(\mathrm{p}=0.0001)$. Sociological surveys revealed a different use of prevention tools by neighborhood, but rates of possession of long-lasting treated mosquito nets and ways of seeking care were similar.

6 Results showed significant spatial disparities in the transmission of malaria in the two neighborhoods studied, while the practices of prevention and health care do not really differ.

Picture 1: Aerial view of the Dar-Es-Salam 1 district with its dense building

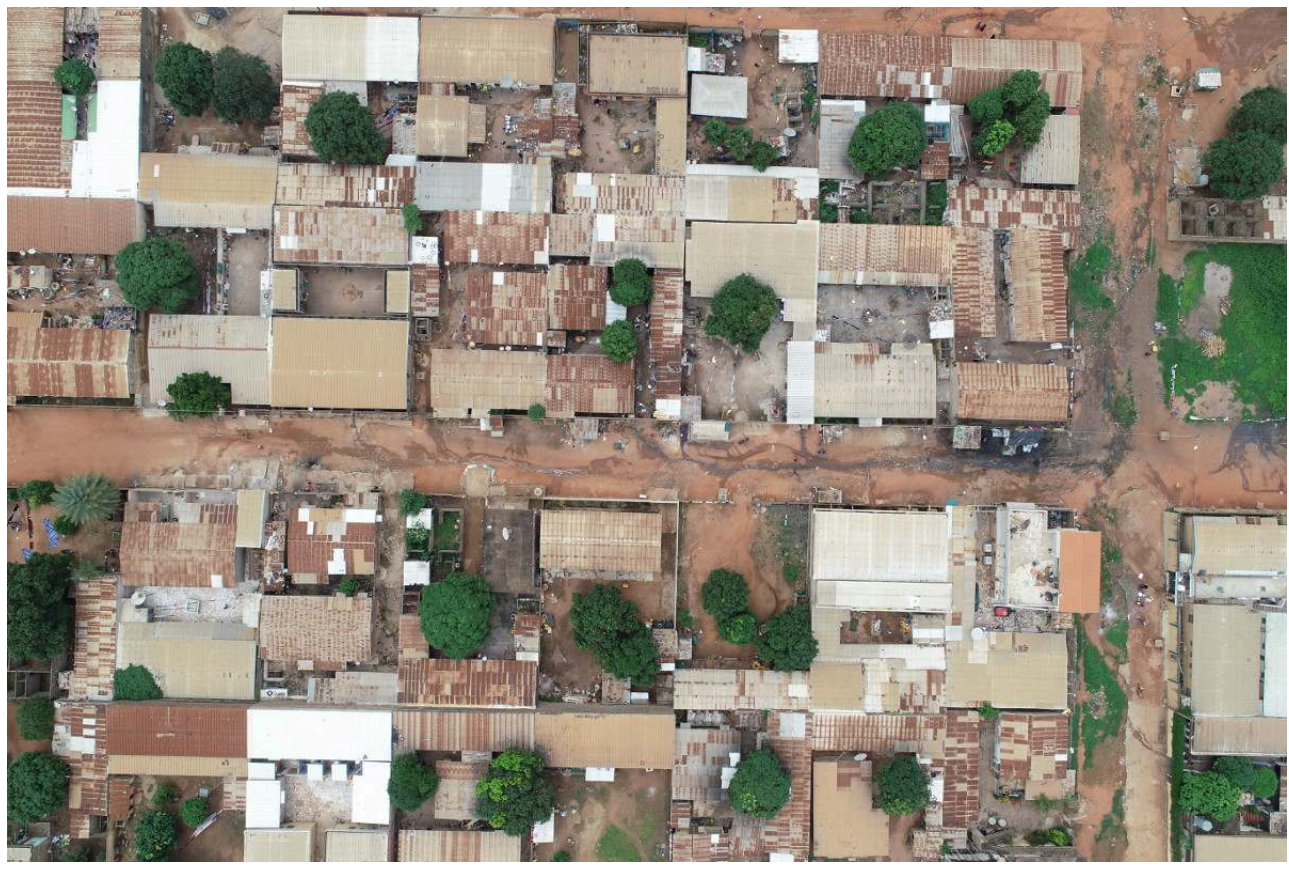

Source: Adou, 2019 
Picture 2: Aerial view of the Kennedy district showing the combination of inhabited and abandoned houses in a highly vegetated environment

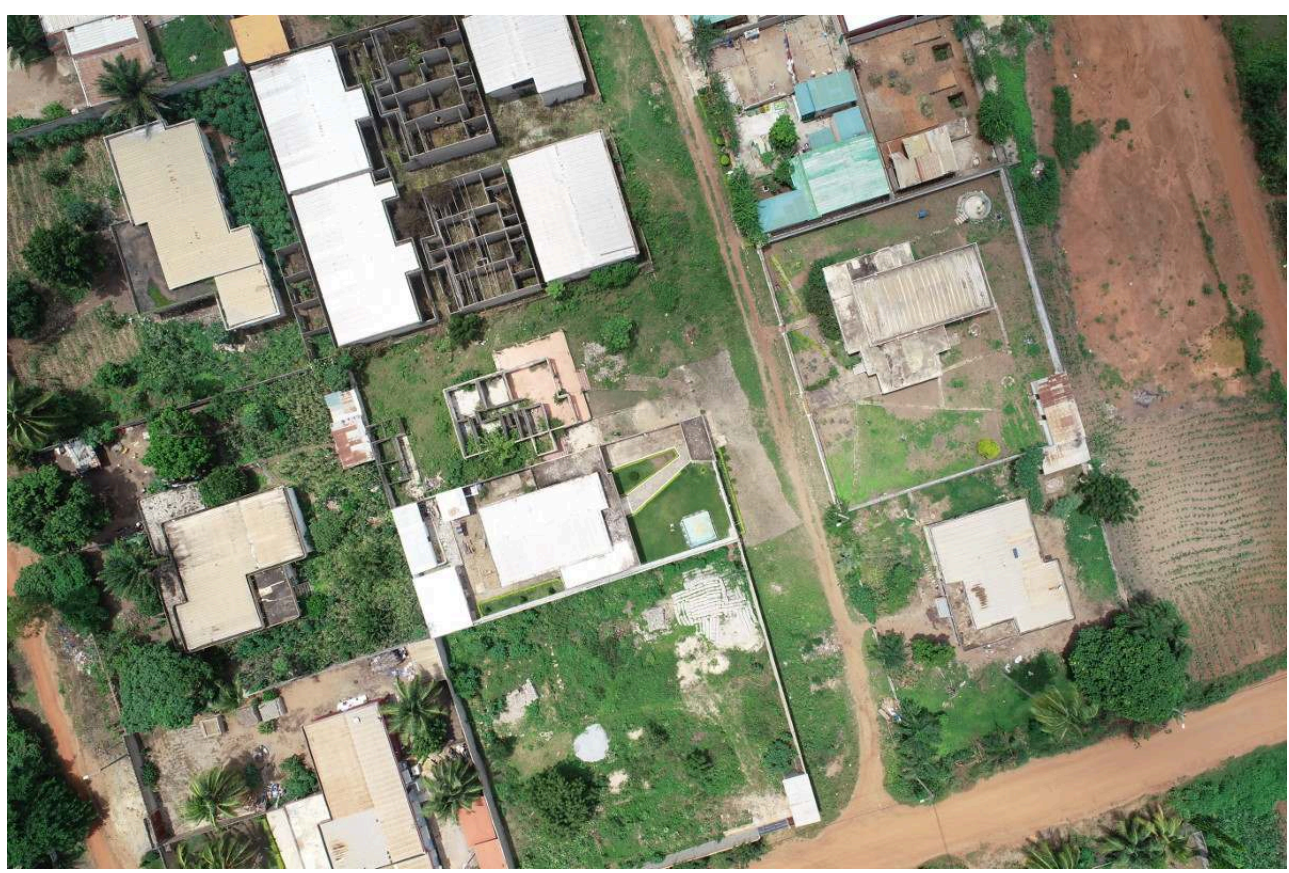

Source: Adou, 2019

\section{INDEX}

Geographical index: Bouaké, Côte d'Ivoire

Keywords: malaria, Anopheles gambiae, land use, human behaviours

Mots-clés: paludisme, Anopheles gambiae, occupation du sol, comportements humains

\section{AUTHORS}

\section{KOUASSI ARSĖNE ADOU}

Institut de Géographie Tropicale, Université Félix Houphouët-Boigny, Côte d'Ivoire

\section{AKRE MAURICE ADJA}

UFR Biosciences, Université Félix Houphouët-Boigny, rattaché à l'Institut Pierre Richet (Institut National de Santé Publique)

\section{DOUNIN DANIELLE ZOH}

UFR Biosciences, Université Félix Houphouët-Boigny, rattachée à l'Institut Pierre Richet (Institut National de Santé Publique), Côte d'Ivoire 


\section{DIMI THÉODORE DOUDOU}

Centre de Recherche pour le Développement, Université Alassane Ouattara, Côte d'Ivoire

PÉGA TUO

Institut de Géographie Tropicale, Université Félix Houphouët-Boigny, Côte d'Ivoire

\section{KOUASSI PAUL ANOH}

Laboratoire « Espaces, Territoires, Sociétés et Santé », Institut de Géographie Tropicale, Université Félix Houphouët-Boigny, Côte d'Ivoire

\section{FLORENCE FOURNET}

MIVEGEC (Univ Montpellier, CNRS, IRD), Institut de Recherche pour le Développement, France 